\title{
Treatment of Neurodevelopmental Disorders in Adulthood
}

\author{
Eero Castrén, ${ }^{1}$ Ype Elgersma, ${ }^{2}$ Lamberto Maffei, ${ }^{3}$ and Randi Hagerman ${ }^{4}$ \\ ${ }^{1}$ Neuroscience Center, University of Helsinki, 00014 Helsinki, Finland, ${ }^{2}$ ENCORE Expertise Center for Neurodevelopmental Disorders, Department of \\ Neuroscience, Erasmus MC, NL-3000 CA Rotterdam, The Netherlands, ${ }^{3}$ Institute of Neuroscience CNR, I-56100, Pisa, Italy, and ${ }^{4}$ MIND Institute, University \\ of California Davis Medical Center, Sacramento, California 95817
}

Brain development in neurodevelopmental disorders has been considered to comprise a sequence of critical periods, and abnormalities occurring during early development have been considered irreversible in adulthood. However, findings in mouse models of neurodevelopmental disorders, including fragile X, Rett syndrome, Down syndrome, and neurofibromatosis type I suggest that it is possible to reverse certain molecular, electrophysiological, and behavioral deficits associated with these disorders in adults by genetic or pharmacological manipulations. Furthermore, recent studies have suggested that critical period-like plasticity can be reactivated in the adult brain by environmental manipulations or by pharmacotherapy. These studies open up a tantalizing possibility that targeted pharmacological treatments in combination with regimes of training or rehabilitation might alleviate or reverse the symptoms of neurodevelopmental disorders even after the end of critical developmental periods. Even though translation from animal experimentation to clinical practice is challenging, these results suggest a rational basis for treatment of neurodevelopmental disorders in adulthood.

\section{Introduction}

Neurodevelopmental disorders first appear during the course of development and maturation, and they are caused by a variety of genetic and environmental conditions (Ehninger et al., 2008). Down syndrome, fragile X syndrome (FXS), Rett syndrome, neurofibromatosis, and tuberous sclerosis are major developmental syndromes leading to intellectual disability (Ehninger et al., 2008; Auerbach et al., 2011; Zoghbi and Bear, 2012), but in the majority of cases, the molecular and neuronal mechanisms underlying the clinical phenotype remain unknown. Neurodevelopmental disorders affect $\sim 1-2 \%$ of the population, and because of their typically life-long course they are very costly. Therefore, even a minor improvement in the performance of these patients would be of great significance to the patients themselves, to families, and to society.

The molecular background of many genetic syndromes leading to neurodevelopmental disorders has been elucidated during the last few years (West and Greenberg, 2011). These findings have paved a way for the discovery of pathways affected in neurodevelopmental disorders and the development of mouse models of these disorders. It has turned out that many of the genes associated with neurodevelopmental disorders play a role in synaptic function (West and Greenberg, 2011; Zoghbi and Bear, 2012), in particular in the regulation of protein synthesis in synapses (Bhakar et al., 2012). These studies have also revealed that in several genes associated with neurodevelopmental disorders,

Received July 11, 2012; revised Aug. 31, 2012; accepted Sept. 1, 2012.

This work was supported by the Sigrid Juselius Foundation and the Academy of Finland Center of Excellence program (E.C.); Nederlandse Organisatie voor Wetenschappelijk Onderzoek (NOW) (Y.E.); and National Institute of Child Health and Human Development Grant HD036071 and Health Resources and Services Administration Grant R40MC22641 (R.H.).

Correspondence should be addressed to Eero Castrén, Neuroscience Center, University of Helsinki, P.0. Box 56, 00014 Helsinki, Finland. E-mail: eero.castren@helsinki.fi.

DOI:10.1523/JNEUROSCI.3287-12.2012

Copyright $\odot 2012$ the authors $\quad 0270-6474 / 12 / 3214074-06 \$ 15.00 / 0$ both reduced and enhanced expression bring about phenotypes, often with strikingly similar clinical features (Ramocki and Zoghbi, 2008), emphasizing the need for precise maintenance of optimal levels of synaptic regulatory proteins. The elucidation of neuronal pathways that are dysfunctional in different neurodevelopmental disorders has inspired a search of drug treatments that may alleviate the cognitive problems (Ehninger et al., 2008; Wetmore and Garner, 2010). It has turned out that enhanced expression of the dysfunctional gene or increased/decreased signaling in the affected pathways at least in some cases partially reversed the symptoms even when the treatment was started only in adulthood, after the full development of the symptoms (Ehninger et al., 2008; Wetmore and Garner, 2010); (Michalon et al., 2012). Clinical trials are currently ongoing to test whether these findings in mouse models are translatable to patients. We will illustrate these exciting advances in more detail below by using FXS and neurofibromatosis type 1 (NF1) as examples.

At the same time, a series of experiments has investigated the molecular and cellular background of developmental critical periods, most often using the well characterized development and plasticity of the mammalian visual cortex as a model. These studies have revealed that a state of plasticity very much resembling that observed during the developmental critical period can be reactivated in the adult visual cortex and other networks through environmental and pharmacological manipulations (Bavelier et al., 2010; Baroncelli et al., 2011). When combined with appropriate rehabilitation, the reactivated juvenile plasticity can lead to a recovery of function in abnormally wired networks, indicating that developmental disorders brought about by abnormal early environment might be treatable in adulthood. Together, these findings open up a new paradigm for the treatment of neurodevelopmental disorders: regulation of affected signaling pathway or reactivation of juvenile-like plasticity, together with appropriate rehabilitation, may lead to a recovery of function and amelioration of abnormal symptoms in a variety of developmental 
disorders. Clinical trials are ongoing to test whether and to what extent these concepts can be translated to human therapy.

\section{Targeted treatments in fragile $\mathrm{X}$ syndrome: from animal models to humans}

FXS is an example of how animal models have led to new targeted treatments that appear to be helpful for not only FXS but also for autism spectrum disorders without an FMR1 mutation (Auerbach et al., 2011; Krueger and Bear, 2011). Studies by Huber and Bear (2002) first identified upregulation of the mGluR5 pathway in the FMR1 KO mouse. This has been confirmed by multiple studies in the mouse and Drosophila models of FXS, and treatment of these animal models with mGluR5 antagonists have led to improvements in the fragile $\mathrm{X}$ phenotype of these animals including synaptic maturation deficits, seizures, hyperactivity, prepulse inhibition abnormalities, learning deficits, and anxiety problems (McBride et al., 2005; de Vrij et al., 2008) (for review, see Hagerman et al., 2012). These exciting results led to human trials of mGluR5 antagonists, including AFQ056 (Novartis) and R04917523 (Roche), that are currently in process. Preliminary results were positive for fenobam in a single dose in adults with FXS (Berry-Kravis et al., 2009), and for AFQ056 in patients with a fully methylated full mutation (Jacquemont et al., 2011). These preliminary results demonstrate improvement in aspects of behavior, although whether there will be cognitive improvements is yet to be seen.

The autism world was electrified by a recent report regarding treatment with a negative allosteric modulator of mGluR5, GRN592, that improved repetitive behavior, stereotypic jumping, and lack of sociability in two mouse models of autism, the BTBR mouse and the C58/J mouse (Silverman et al., 2012). These results suggest that the targeted treatments for FXS will be helpful for autism also.

An additional targeted treatment that lowers glutamate at the synapse through stimulation of $\mathrm{GABA}_{\mathrm{B}}$ receptors presynaptically, arbaclofen, has also shown benefit in a controlled trial in children and adults with FXS who have autism or significant social deficits (Berry-Kravis et al., in press). Preliminary studies in autism suggest that arbaclofen will be helpful for this group of patients also, although again behavior is measured and not cognitive improvements.

FMRP is a regulator of translation for many hundreds of messages from other genes, many of which cause autism when mutated (Darnell et al., 2011). Nearly half of the genes identified as associated with autism are also associated with FMRP (Iossifov et al., 2012). Therefore, the absence of FMRP in FXS leads to dysregulation of other proteins that are targets for treatment in FXS and perhaps for autism. For instance, elevation of matrix metalloproteinase 9 has been documented in the FMR1 KO mouse, and treatment with minocycline after birth rescues the immature dendritic spine phenotype and improves the cognitive and behavioral phenotype of the treated mice (Bilousova et al., 2009). In the fragile X Drosophila model, treatment with minocycline rescues the immature spines and the behavioral phenotype of the fly (Siller and Broadie, 2012). Studies in patients with FXS demonstrated behavioral benefits in a survey, an open label trial, and a controlled trial of minocycline (Paribello et al., 2010; Utari et al., 2010) (M. J. S. Leigh, D. V. Ngyen, T. I. Winarni, A. Schneider, T. Chechi, J. Polussa, P. Douchet, F. Tassone, S. M. Rivera, D. Hessl, and R. Hagerman, unpublished data).

Deficits in the $\mathrm{GABA}_{\mathrm{A}}$ receptor pathway have been demonstrated in the mouse model of FXS, and treatment with a $\mathrm{GABA}_{\mathrm{A}}$ receptor agonist, ganaxolone, is helpful in the mouse and is cur- rently being studied in children with FXS (Heulens et al., 2012). Other targeted treatments that are focused on inhibiting proteins that are dysregulated in FXS such as the inhibition of GSK3 $\beta$, inhibition of PAK, inhibition of PI3K, and inhibition of ERK/ MEK have shown favorable results in the animal models (for review, see Gross et al., 2012; Hagerman et al., 2012). Lithium, available currently by prescription, inhibits GSK $3 \beta$, downregulates mGluR5, and has demonstrated behavioral benefits in an open label trial in patients with FXS (Berry-Kravis et al., 2008). NMDA antagonists, including acamprosate (Erickson et al., 2010) and memantine (Winarni et al., 2012), were helpful in a few patients with FXS, and a controlled multicenter trial of memantine is ongoing in autism without FXS.

Parents of adult children with FXS and researchers were delighted with the results of the study of Michalon et al. (2012) where young adult FMR1 KO mice with an established FXS phenotype demonstrated improvements in cognitive deficits, auditory hypersensitivity, overactive ERK, and mammalian target of rapamycin signaling and even macroorchidism with chronic treatment with CTEP, a long-acting mGluR5 antagonist. Such studies give us all hope that reversal of the fragile $\mathrm{X}$ phenotype may be possible, even in adulthood. However, recent studies indicate that the loss of FMRP is associated with deficiencies at multiple developmental stages, including differentiation of human neural stem cells (Castrén et al., 2005; Tervonen et al., 2009; Sheridan et al., 2011). Therefore, reversal of FXS in humans will likely require a combination of targeted treatments because of the multiple pathways that are affected with the loss of FMRP. In addition, learning programs to reteach academic and life skills will be needed as the synaptic connections improve and as patients are able to retain what they learn.

\section{Neurofibromatosis type 1: the GAP from mice to treatment}

The RAS signaling pathway has been shown to be important for cognitive function in mice and humans (Krab et al., 2008c). Disorders that are associated with this pathway such as NF1, Noonan syndrome, Costello syndrome, Legius syndrome, cardio-facio-cutaneous syndrome, and LEOPARD syndrome, are now collectively referred to as the rasopathies (Tidyman and Rauen, 2009). Cognitive deficits are observed in many of these patients. Importantly, the deficits do not appear to be caused by gross pathological abnormalities of the brain. Rather, they appear to originate from abnormal synaptic function due to increased activation of the RAS-ERK signaling pathway. This aspect holds great opportunities for a potential treatment, in particular because many drugs directed against this pathway are already on the market and used in oncology.

NF1 (incidence 1:3000) is the best studied rasopathy. It is an autosomal-dominant disorder, caused by mutations in the NF1 gene, which encodes neurofibromin, a GAP domain-containing protein that inactivates RAS (Shilyansky et al., 2010b). NF1 is characterized by cutaneous and plexiform neurofibromas, café au lait spots, axillary freckling, and Lisch nodules. Even though the cognitive deficits appear to be rather mild (IQ 85-90) (Hyman et al., 2005), these deficits have a large impact on school performance and quality of life (Krab et al., 2008a,b). Mice with a heterozygous null mutation of the $\mathrm{Nf1}$ gene $\left(\mathrm{Nf1}^{+/-}\right.$mice) show compelling genetic and behavioral parallels with human NF1, including impairments in visual-spatial learning, working memory, attention, and motor performance (Silva et al., 1997; Costa et al., 2002; Shilyansky et al., 2010a; van der Vaart et al., 2011). Pioneering studies from the Silva Laboratory showed that these deficits are caused by increased GABAergic signaling (Costa et al., 
2002; Cui et al., 2008). More importantly, they showed that attenuation of the RAS-ERK pathway reversed the deficits in mice.

Particularly promising is the observation that statins can also rescue the learning deficits in $N f 1^{+/-}$mice, presumably by their ability to interfere with the cholesterol synthesis pathway, and rendering the cell with a reduced amount of farnesyl, which is required for RAS function ( $\mathrm{Li}$ et al., 2005). The fact that statins are one of the most commonly prescribed drugs allowed a rapid translation to a phase II clinical study (Krab et al., 2008a). A randomized placebo-controlled trial involving 62 children gave a mixed result (Krab et al., 2008a). Moreover, this trial showed that translating these promising mouse results to the clinic comes with challenges. First of all, the treatment time needed to observe (or expect) cognitive changes is hard to assess. Although adult 2-month-old mice show improved learning after days of treatment, it is likely that neurons and networks of a 10-year-old human child have adapted to the increased ERK signaling and have evolved homeostatic adaptation mechanisms at the cellular and systems level to deal with this perturbation. Moreover, a short treatment may result in a significant improvement because of the test-retest effect. For instance, in the trial of Krab et al. (2008a), four of nine tests showed a significant improvement in the placebo group, potentially masking the effect of statins. The second challenge is determining the best outcome measure. A few carefully selected outcome measures in which most children are affected and which show high reproducibility with little testretest effect will give the highest statistical power. However, this strategy may be problematic for the participants who had no problem with these specific tests, but nevertheless show learning disabilities. This is in particular the case with NF1 where the cognitive profile varies profoundly from child to child. Excluding such children beforehand could result in excluding children who would benefit from a treatment and reduces the external validity of the trial. In addition, how improvements in a few specific cognitive tests translate to improved quality of everyday life and improved academic performance remains to be investigated. This is the reason why our second, now 1 year treatment, simvastatin study (NTR2150, www.trialregister.nl) uses more general outcome measures, e.g., IQ test and quality of life.

Finally, it is important to realize that, regardless of the trial design, statins may not be potent enough to treat the cognitive deficits in NF1 patients, as they were also not good enough to treat cancer despite some promising results in vitro. Hence, it is worthwhile to go back to the mouse model and investigate how the selective increase of inhibition in $N f 1$ mice arises, and how this can be targeted directly. Identifying these mechanisms may result in new treatment opportunities not only for neurofibromatosis, but for other rasopathies as well.

\section{Reactivation of critical period plasticity in adult visual cortex by enriched environment}

Neuronal plasticity can be defined as the capacity of neurons and neural circuits in the brain to change structurally and functionally in response to experience. Neural plasticity is crucial for the development of brain and behavior, and it is at the basis of the brain's remarkable performances, including learning and memory. Furthermore, plasticity is instrumental for brain repair.

Recent studies have shown, using mammalian visual cortex as an experimental model (Berardi et al., 2000; Hensch, 2005), that it is possible to reinstate much greater levels of plasticity in the adult visual cortex than previously suspected, using various environmental and pharmacological strategies (Sale et al., 2010). Environmental enrichment (EE; i.e., an environment that is rich in social, physical, cognitive, and inanimate stimulation) has long been exploited to investigate the influence of the environment on brain structure and function (Sale et al., 2009). Recent findings have brought to light new effects of the richness of the environment on brain development and, in particular, on brain's plasticity during adulthood. In addition to visual acuity (visual resolution power), ocular dominance has been used to measure visual cortical plasticity; reduction of the visual input in one eye, for instance by means of lid suture, strongly reduces the number of visual cortical neurons driven by the deprived eye. This effect is present only during a short period after birth called the critical period. If this kind of functional imbalance between the two eyes is present early in development and it is not corrected by the end of the critical period, a permanent impairment known as amblyopia (lazy eye) ensues (Maurer and Hensch, 2012).

Earlier studies have shown that EE promotes the development of the visual cortex (Cancedda et al., 2004) and that nonvisual factors can contribute to visual cortical development (Bartoletti et al., 2004). EE effects on visual cortex development are mediated by endogenous molecular factors involved in visual cortical development and plasticity, such as brain-derived neurotrophic factor (BDNF) and intracortical inhibition (Bartoletti et al., 2004). The effects of inhibitory synapses are indeed crucial for the end of the critical period and modulation of plasticity during adulthood. These studies have also shown that retinal development is sensitive to EE (Landi et al., 2007) and have brought to light a very new role, both at retinal and cortical level, for insulinlike growth factor-1 (IGF-1) (Landi et al., 2009).

More recent studies have shown that EE in terms of body massage promotes brain development, and in particular visual development, in rat pups and, importantly, also in premature and regularly born human infants (Guzzetta et al., 2009). This effect is likely mediated by IGF-1. These studies suggest a new role for IGF-1, giving this molecule the status of a factor crucial for the development of different visual structures and with significant therapeutic potential.

A remarkable set of experiments then showed for the first time that EE restores plasticity of the visual cortex in adulthood (Sale et al., 2007). Furthermore, the exposure of adult rats to EE completely rescued the visual deficits associated with amblyopia (Sale et al., 2007). EE effects on adult visual cortex plasticity are likely mediated by an action on intracortical inhibition, a crucial determinant for critical period regulation in the visual system (Harauzov et al., 2010; Sale et al., 2010). The relative contributions of the different components of EE to adult visual cortical plasticity, enhancement, and recovery from amblyopia have also been dissected, showing that the components effective in rescuing visual deficits are those that act on intracortical inhibition.

These new findings highlight the potential of EE as a noninvasive intervention strategy to ameliorate deficits in the maturation of the nervous system and to promote recovery of normal sensory functions in pathological conditions affecting the adult brain. Along these lines, a protocol of behavioral practice leading to perceptual learning was recently developed in rodents, showing that this protocol increases the efficacy of intracortical connections in the primary visual cortex and showing that it is effective in promoting recovery from amblyopia (Baroncelli et al., 2012).

Finally, quite recent studies have shown that restriction of food can restore plasticity in the visual cortex of the adult rats, accompanied, as in the case of EE, by a decrease of inhibition and an increase of BDNF (Spolidoro et al., 2011). In addition, EE is active not only in the visual cortex and hippocampus, but also in 
other parts of the brain, for instance in the arcuate nucleus of the hypothalamus, by altering the ratio of excitation and inhibition, with the result of increasing the sensitivity to leptin and thus regulating food intake (Mainardi et al., 2010). This experiment on the hypothalamus indicates that the effects of $\mathrm{EE}$ are quite general on the whole brain and with similar mechanisms.

\section{Pharmacological reactivation of early life-like plasticity in adulthood}

In addition to environmental manipulations, pharmacological treatments have also been shown to reactivate juvenile-like plastic state in brain (Bavelier et al., 2010; Baroncelli et al., 2011). Again, visual cortex has been used as a model paradigm in most studies, but there is evidence that these treatments induce early life-like plasticity in other networks as well.

The first pharmacological treatment that was shown to reactivate critical period-like plasticity in the adult brain was infusion of nerve growth factor (NGF) into the visual cortex of adult cats (Gu et al., 1994; Galuske et al., 2000). Similarly, injection of an enzyme, chondroitinase ABC (ChABC), locally into the adult rat visual cortex induced structural and functional plasticity (Pizzorusso et al., 2002, 2006). This treatment has been shown to disrupt perineuronal nets, proteoglycan-rich extracellular structures that form particularly around inhibitory interneurons during postnatal development, coinciding with the closure of the critical period (Berardi et al., 2004). Although treatments with chondroitinase ABS and NGF have been shown to be effective in inducing a critical period-like plasticity in the rodent visual cortex, the invasiveness of these treatments limits their clinical significance.

Antidepressant drugs have been shown to enhance signs of neuronal plasticity, such as hippocampal neurogenesis and the expression and signaling of BDNF in adult brain (Duman and Monteggia, 2006; Martinowich et al., 2007). Recent studies showed that chronic treatment of adult rats with the antidepressant fluoxetine induced a plastic state in the visual cortex that closely resembles that observed at the peak of the critical period (Maya Vetencourt et al., 2008). Furthermore, visual acuity of the amblyopic eye could be fully restored in adulthood when the eye was opened during fluoxetine treatment and the previously open eye was simultaneously closed to encourage the use of the weak eye (Maya Vetencourt et al., 2008). Fluoxetine-induced adult plasticity correlated with reduction in GABA-mediated inhibition, required the increase expression of BDNF and activation of 5HT1A serotonin receptors (Maya Vetencourt et al., 2008, 2011). An independent study that used two-photon imaging in vivo revealed that fluoxetine treatment induced a simultaneous increase in the extension and retraction of synaptic contacts of inhibitory neurons in adult brain (Chen et al., 2011).

Since fluoxetine has been widely consumed over the last few decades, it is clear that a large number of amblyopic patients have been exposed to it. Therefore, fluoxetine treatment alone is not sufficient to treat amblyopia, but it is still possible that fluoxetine in combination with eye-patching might be beneficial in adult amblyopic patients. A clinical trial testing this possibility is currently ongoing in Finland. Interestingly, the amplitude of visually evoked potentials after an intense visual stimulation was significantly elevated in healthy volunteers treated with sertraline, another antidepressant drug (Normann et al., 2007), a finding comparable to that observed in rats after fluoxetine treatment, supporting the idea that antidepressants may enhance visual cortical plasticity in adult humans as well as in rats.
Other drugs in addition to fluoxetine have been shown to produce a similar reactivation of juvenile-like plasticity in the adult visual cortex. Inhibitors of histone deacetylase were shown to induce critical period-like plasticity in the rat visual cortex, indicating that epigenetic regulation of chromatin state plays a role in adult plasticity (Putignano et al., 2007). Furthermore, physostigmine, a cholinesterase inhibitor, was shown to produce similar effects in the mouse visual cortex (Bavelier et al., 2010; Morishita et al., 2010).

Pharmacological reactivation of juvenile-like plasticity is not confined to the visual cortex. Local injections of ChABC promote functional recovery after a spinal cord lesion (Bradbury et al., 2002), and very recent data suggest that a similar kind of plastic state can be achieved with fluoxetine (Scali et al., 2012). Furthermore, a recent study that used fear conditioning and extinction training as a model provided evidence that chronic fluoxetine treatment reactivates juvenile-like plastic state in the basolateral amygdala and thereby promotes the effects of fear extinction (Karpova et al., 2011), suggesting a neurobiological explanation for the enhanced effects of combined antidepressant treatment and psychotherapy. These data suggest that fluoxetine and perhaps also other drug treatments influencing plasticity in the visual cortex have wide-ranging effects on neuronal plasticity in several neuronal networks. Indeed, fluoxetine has been shown to be effective in the recovery from stroke (Acler et al., 2009; Jorge et al., 2010; Chollet et al., 2011), which might, at least in part, be explained by fluoxetine-induced plasticity and facilitation of the effect of rehabilitation.

Together with the effects of environmental manipulations reviewed above, these findings indicate that a surprisingly wide variety of environmental or pharmacological treatments can induce a plastic state in adult brain that resembles that present during the critical period of juvenile brain development. Many of these drugs have been widely used over decades, making clear that these treatments do not represent any "fountain of youth". Nevertheless, significant plasticity-inducing effects of these drugs may have gone unnoticed because of the fact that, for maximal clinical efficacy, drug treatment needs to be complemented with appropriate rehabilitation that guides the plastic networks for functional restoration. The ongoing clinical trials will eventually tell whether these effects observed in rodents are translatable to human therapy.

\section{Summary}

Neurodevelopmental disorders are relatively common conditions ranging from mild to severe and producing life-long disability and behavioral abnormalities that are a burden to families. Recent rodent studies reviewed here suggest that disabilities and symptoms produced by developmental disorders might be alleviated or even cured in adulthood. Clinical trials testing whether the findings in experimental studies can be translated into clinical medicine are already ongoing. It is to be expected that all these treatments will greatly benefit from structured regimes of training or rehabilitation that need to be developed alongside the pharmacological treatments. Together, these findings suggest a rational basis for treatment of developmental disorders in adulthood, a prospect that provides hope to millions of individuals and families.

\section{References}

Acler M, Robol E, Fiaschi A, Manganotti P (2009) A double blind placebo RCT to investigate the effects of serotonergic modulation on brain excitability and motor recovery in stroke patients. J Neurol 256:1152-1158. CrossRef Medline 
Auerbach BD, Osterweil EK, Bear MF (2011) Mutations causing syndromic autism define an axis of synaptic pathophysiology. Nature 480:63-68. CrossRef Medline

Baroncelli L, Braschi C, Spolidoro M, Begenisic T, Maffei L, Sale A (2011) Brain plasticity and disease: a matter of inhibition. Neural Plast 2011: 286073. CrossRef Medline

Baroncelli L, Bonaccorsi J, Milanese M, Bonifacino T, Giribaldi F, Manno I, Cenni MC, Berardi N, Bonanno G, Maffei L, Sale A (2012) Enriched experience and recovery from amblyopia in adult rats: impact of motor, social and sensory components. Neuropharmacology 62:2388-2397. CrossRef Medline

Bartoletti A, Medini P, Berardi N, Maffei L (2004) Environmental enrichment prevents effects of dark-rearing in the rat visual cortex. Nat Neurosci 7:215-216. CrossRef Medline

Bavelier D, Levi DM, Li RW, Dan Y, Hensch TK (2010) Removing brakes on adult brain plasticity: from molecular to behavioral interventions. J Neurosci 30:14964-14971. CrossRef Medline

Berardi N, Pizzorusso T, Maffei L (2000) Critical periods during sensory development. Curr Opin Neurobiol 10:138-145. CrossRef Medline

Berardi N, Pizzorusso T, Maffei L (2004) Extracellular matrix and visual cortical plasticity: freeing the synapse. Neuron 44:905-908. CrossRef Medline

Berry-Kravis E, Sumis A, Hervey C, Nelson M, Porges SW, Weng N, Weiler IJ, Greenough WT (2008) Open-label treatment trial of lithium to target the underlying defect in fragile X syndrome. J Dev Behav Pediatr 29:293302. CrossRef Medline

Berry-Kravis E, Hessl D, Coffey S, Hervey C, Schneider A, Yuhas J, Hutchison J, Snape M, Tranfaglia M, Nguyen DV, Hagerman R (2009) A pilot open label, single dose trial of fenobam in adults with fragile X syndrome. J Med Genet 46:266-271. CrossRef Medline

Berry-Kravis EM, Hessl D, Rathmell B, Zarevics P, Cherubini M, WaltonBowen K, Mu Y, Nguyen DV, Gonzalez-Heydrich J, Wang PP, Carpenter RL, Bear MF, Hagerman RJ (2012) Effects of STX209 (arbaclofen) on neurobehavioral function in children and adults with fragile $\mathrm{X}$ syndrome: a randomized, controlled, phase 2 trial. Sci Transl Med 4:153ra127. CrossRef Medline

Bhakar AL, Dölen G, Bear MF (2012) The pathophysiology of fragile X (and what it teaches us about synapses). Annu Rev Neurosci 35:417-443. CrossRef Medline

Bilousova TV, Dansie L, Ngo M, Aye J, Charles JR, Ethell DW, Ethell IM (2009) Minocycline promotes dendritic spine maturation and improves behavioural performance in the fragile X mouse model. J Med Genet 46:94-102. Medline

Bradbury EJ, Moon LD, Popat RJ, King VR, Bennett GS, Patel PN, Fawcett JW, McMahon SB (2002) Chondroitinase ABC promotes functional recovery after spinal cord injury. Nature 416:636-640. CrossRef Medline

Cancedda L, Putignano E, Sale A, Viegi A, Berardi N, Maffei L (2004) Acceleration of visual system development by environmental enrichment. J Neurosci 24:4840-4848. CrossRef Medline

Castrén M, Tervonen T, Kärkkäinen V, Heinonen S, Castrén E, Larsson K, Bakker CE, Oostra BA, Åkerman K (2005) Altered differentiation of neural stem cells in fragile X syndrome. Proc Natl Acad Sci U S A 102: 17834-17839. CrossRef Medline

Chen JL, Lin WC, Cha JW, So PT, Kubota Y, Nedivi E (2011) Structural basis for the role of inhibition in facilitating adult brain plasticity. Nat Neurosci 14:587-594. CrossRef Medline

Chollet F, Tardy J, Albucher JF, Thalamas C, Berard E, Lamy C, Bejot Y, Deltour S, Jaillard A, Niclot P, Guillon B, Moulin T, Marque P, Pariente J, Arnaud C, Loubinoux I (2011) Fluoxetine for motor recovery after acute ischaemic stroke (FLAME): a randomised placebo-controlled trial. Lancet Neurol 10:123-130. CrossRef Medline

Costa RM, Federov NB, Kogan JH, Murphy GG, Stern J, Ohno M, Kucherlapati R, Jacks T, Silva AJ (2002) Mechanism for the learning deficits in a mouse model of neurofibromatosis type 1. Nature 415:526-530. CrossRef Medline

Cui Y, Costa RM, Murphy GG, Elgersma Y, Zhu Y, Gutmann DH, Parada LF, Mody I, Silva AJ (2008) Neurofibromin regulation of ERK signaling modulates GABA release and learning. Cell 135:549-560. CrossRef Medline

Darnell JC, Van Driesche SJ, Zhang C, Hung KY, Mele A, Fraser CE, Stone EF, Chen C, Fak JJ, Chi SW, Licatalosi DD, Richter JD, Darnell RB (2011)
FMRP stalls ribosomal translocation on mRNAs linked to synaptic function and autism. Cell 146:247-261. CrossRef Medline

de Vrij FM, Levenga J, van der Linde HC, Koekkoek SK, De Zeeuw CI, Nelson DL, Oostra BA, Willemsen R (2008) Rescue of behavioral phenotype and neuronal protrusion morphology in Fmr1 KO mice. Neurobiol Dis 31:127-132. CrossRef Medline

Duman RS, Monteggia LM (2006) A neurotrophic model for stress-related mood disorders. Biol Psychiatry 59:1116-1127. CrossRef Medline

Ehninger D, Li W, Fox K, Stryker MP, Silva AJ (2008) Reversing neurodevelopmental disorders in adults. Neuron 60:950-960. CrossRef Medline

Erickson CA, Mullett JE, McDougle CJ (2010) Brief report: acamprosate in fragile X syndrome. J Autism Dev Disord 40:1412-1416. CrossRef Medline

Galuske RA, Kim DS, Castrén E, Singer W (2000) Differential effects of neurotrophins on ocular dominance plasticity in developing and adult cat visual cortex. Eur J Neurosci 12:3315-3330. CrossRef Medline

Gross C, Berry-Kravis EM, Bassell GJ (2012) Therapeutic strategies in fragile $\mathrm{X}$ syndrome: dysregulated mGluR signaling and beyond. Neuropsychopharmacology 37:178-195. CrossRef Medline

Gu Q, Liu Y, Cynader MS (1994) Nerve growth factor-induced ocular dominance plasticity in adult cat visual cortex. Proc Natl Acad Sci U S A 91: 8408-8412. CrossRef Medline

Guzzetta A, Baldini S, Bancale A, Baroncelli L, Ciucci F, Ghirri P, Putignano E, Sale A, Viegi A, Berardi N, Boldrini A, Cioni G, Maffei L (2009) Massage accelerates brain development and the maturation of visual function. J Neurosci 29:6042-6051. CrossRef Medline

Hagerman R, Lauterborn J, Au J, Berry-Kravis E (2012) Fragile X syndrome and targeted treatment trials. Results Probl Cell Differ 54:297-335. CrossRef Medline

Harauzov A, Spolidoro M, DiCristo G, De Pasquale R, Cancedda L, Pizzorusso T, Viegi A, Berardi N, Maffei L (2010) Reducing intracortical inhibition in the adult visual cortex promotes ocular dominance plasticity. J Neurosci 30:361-371. CrossRef Medline

Hensch TK (2005) Critical period plasticity in local cortical circuits. Nat Rev Neurosci 6:877-888. CrossRef Medline

Heulens I, D’Hulst C, Van Dam D, De Deyn PP, Kooy RF (2012) Pharmacological treatment of fragile X syndrome with GABAergic drugs in a knockout mouse model. Behav Brain Res 229:244-249. CrossRef Medline

Huber KM, Gallagher SM, Warren ST, Bear MF (2002) Altered synaptic plasticity in a mouse model of fragile X mental retardation. Proc Natl Acad Sci U S A 99:7746-7750. CrossRef Medline

Hyman SL, Shores A, North KN (2005) The nature and frequency of cognitive deficits in children with neurofibromatosis type 1 . Neurology 65 : 1037-1044. CrossRef Medline

Iossifov I, Ronemus M, Levy D, Wang Z, Hakker I, Rosenbaum J, Yamrom B, Lee YH, Narzisi G, Leotta A, Kendall J, Grabowska E, Ma B, Marks S, Rodgers L, Stepansky A, Troge J, Andrews P, Bekritsky M, Pradhan K, Ghiban E, Kramer M, Parla J, Demeter R, Fulton LL, Fulton RS, Magrini VJ, Ye K, Darnell JC, Darnell RB, Mardis ER, Wilson RK, Schatz MC, McCombie WR, Wigler M (2012) De novo gene disruptions in children on the autistic spectrum. Neuron 74:285-299. CrossRef Medline

Jacquemont S, Curie A, des Portes V, Torrioli MG, Berry-Kravis E, Hagerman RJ, Ramos FJ, Cornish K, He Y, Paulding C, Neri G, Chen F, Hadjikhani N, Martinet D, Meyer J, Beckmann JS, Delange K, Brun A, Bussy G, Gasparini F, et al. (2011) Epigenetic modification of the FMR1 gene in fragile $\mathrm{X}$ syndrome is associated with differential response to the mGluR5 antagonist AFQ056. Sci Transl Med 3:64ra1. CrossRef Medline

Jorge RE, Acion L, Moser D, Adams HP Jr, Robinson RG (2010) Escitalopram and enhancement of cognitive recovery following stroke. Arch Gen Psychiatry 67:187-196. CrossRef Medline

Karpova NN, Pickenhagen A, Lindholm J, Tiraboschi E, Kulesskaya N, Agústsdottir A, Antila H, Popova D, Akamine Y, Bahi A, Sullivan R, Hen R, Drew LJ, Castrén E (2011) Fear erasure in mice requires synergy between antidepressant drugs and extinction training. Science 334:17311734. CrossRef Medline

Krab LC, de Goede-Bolder A, Aarsen FK, Pluijm SM, Bouman MJ, van der Geest JN, Lequin M, Catsman CE, Arts WF, Kushner SA, Silva AJ, de Zeeuw CI, Moll HA, Elgersma Y (2008a) Effect of simvastatin on cognitive functioning in children with neurofibromatosis type 1: a randomized controlled trial. JAMA 300:287-294. CrossRef Medline

Krab LC, Aarsen FK, de Goede-Bolder A, Catsman-Berrevoets CE, Arts WF, 
Moll HA, Elgersma Y (2008b) Impact of neurofibromatosis type 1 on school performance. J Child Neurol 23:1002-1010. CrossRef Medline

Krab LC, Goorden SM, Elgersma Y (2008c) Oncogenes on my mind: ERK and MTOR signaling in cognitive diseases. Trends Genet 24:498-510. CrossRef Medline

Krueger DD, Bear MF (2011) Toward fulfilling the promise of molecular medicine in fragile X syndrome. Annu Rev Med 62:411-429. CrossRef Medline

Landi S, Sale A, Berardi N, Viegi A, Maffei L, Cenni MC (2007) Retinal functional development is sensitive to environmental enrichment: a role for BDNF. FASEB J 21:130-139. CrossRef Medline

Landi S, Ciucci F, Maffei L, Berardi N, Cenni MC (2009) Setting the pace for retinal development: environmental enrichment acts through insulin-like growth factor 1 and brain-derived neurotrophic factor. J Neurosci 29: 10809-10819. CrossRef Medline

Li W, Cui Y, Kushner SA, Brown RA, Jentsch JD, Frankland PW, Cannon TD, Silva AJ (2005) The HMG-CoA reductase inhibitor lovastatin reverses the learning and attention deficits in a mouse model of neurofibromatosis type 1. Curr Biol 15:1961-1967. CrossRef Medline

Mainardi M, Scabia G, Vottari T, Santini F, Pinchera A, Maffei L, Pizzorusso T, Maffei M (2010) A sensitive period for environmental regulation of eating behavior and leptin sensitivity. Proc Natl Acad Sci U S A 107:16673-16678. CrossRef Medline

Martinowich K, Manji H, Lu B (2007) New insights into BDNF function in depression and anxiety. Nat Neurosci 10:1089-1093. CrossRef Medline

Maurer D, Hensch TK (2012) Amblyopia: background to the special issue on stroke recovery. Dev Psychobiol 54:224-238. CrossRef Medline

Maya Vetencourt JF, Sale A, Viegi A, Baroncelli L, De Pasquale R, O’Leary OF, Castrén E, Maffei L (2008) The Antidepressant Fluoxetine Restores Plasticity in the Adult Visual Cortex. Science 320:385-388. CrossRef Medline

Maya Vetencourt JF, Tiraboschi E, Spolidoro M, Castrén E, Maffei L (2011) Serotonin triggers a transient epigenetic mechanism that reinstates adult visual cortex plasticity in rats. Eur J Neurosci 33:49-57. CrossRef Medline

McBride SM, Choi CH, Wang Y, Liebelt D, Braunstein E, Ferreiro D, Sehgal A, Siwicki KK, Dockendorff TC, Nguyen HT, McDonald TV, Jongens TA (2005) Pharmacological rescue of synaptic plasticity, courtship behavior, and mushroom body defects in a Drosophila model of fragile X syndrome. Neuron 45:753-764. CrossRef Medline

Michalon A, Sidorov M, Ballard TM, Ozmen L, Spooren W, Wettstein JG, Jaeschke G, Bear MF, Lindemann L (2012) Chronic pharmacological mGlu5 inhibition corrects fragile $\mathrm{X}$ in adult mice. Neuron 74:49-56. CrossRef Medline

Morishita H, Miwa JM, Heintz N, Hensch TK (2010) Lynxl, a cholinergic brake, limits plasticity in adult visual cortex. Science 330:1238-1240. CrossRef Medline

Normann C, Schmitz D, Fürmaier A, Döing C, Bach M (2007) Long-term plasticity of visually evoked potentials in humans is altered in major depression. Biol Psychiatry 62:373-380. CrossRef Medline

Paribello C, Tao L, Folino A, Berry-Kravis E, Tranfaglia M, Ethell IM, Ethell DW (2010) Open-label add-on treatment trial of minocycline in fragile X syndrome. BMC Neurol 10:91. CrossRef Medline

Pizzorusso T, Medini P, Berardi N, Chierzi S, Fawcett JW, Maffei L (2002) Reactivation of ocular dominance plasticity in the adult visual cortex. Science 298:1248-1251. CrossRef Medline

Pizzorusso T, Medini P, Landi S, Baldini S, Berardi N, Maffei L (2006) Structural and functional recovery from early monocular deprivation in adult rats. Proc Natl Acad Sci U S A 103:8517-8522. CrossRef Medline

Putignano E, Lonetti G, Cancedda L, Ratto G, Costa M, Maffei L, Pizzorusso T (2007) Developmental downregulation of histone posttranslational modifications regulates visual cortical plasticity. Neuron 53:747-759. CrossRef Medline

Ramocki MB, Zoghbi HY (2008) Failure of neuronal homeostasis results in common neuropsychiatric phenotypes. Nature 455:912-918. CrossRef Medline

Sale A, Maya Vetencourt JF, Medini P, Cenni MC, Baroncelli L, De Pasquale
R, Maffei L (2007) Environmental enrichment in adulthood promotes amblyopia recovery through a reduction of intracortical inhibition. Nat Neurosci 10:679-681. CrossRef Medline

Sale A, Berardi N, Maffei L (2009) Enrich the environment to empower the brain. Trends Neurosci 32:233-239. CrossRef Medline

Sale A, Berardi N, Spolidoro M, Baroncelli L, Maffei L (2010) GABAergic inhibition in visual cortical plasticity. Front Cell Neurosci 4:10. CrossRef Medline

Scali M, Begenisic T, Mainardi M, Sale A, Maffei L (2012) Chronic treatment with fluoxetine promotes recovery from cervical spinal cord injury in rats. FENS Forum abstract 1443. http://fens.ekonnect.co/FENS_331/ poster_33606/program.aspx.

Sheridan SD, Theriault KM, Reis SA, Zhou F, Madison JM, Daheron L, Loring JF, Haggarty SJ (2011) Epigenetic characterization of the FMR1 gene and aberrant neurodevelopment in human induced pluripotent stem cell models of fragile X syndrome. PLoS One 6:e26203. CrossRef Medline

Shilyansky C, Karlsgodt KH, Cummings DM, Sidiropoulou K, Hardt M, James AS, Ehninger D, Bearden CE, Poirazi P, Jentsch JD, Cannon TD, Levine MS, Silva AJ (2010a) Neurofibromin regulates corticostriatal inhibitory networks during working memory performance. Proc Natl Acad Sci U S A 107:13141-13146. CrossRef Medline

Shilyansky C, Lee YS, Silva AJ (2010b) Molecular and cellular mechanisms of learning disabilities: a focus on NF1. Annu Rev Neurosci 33:221-243. CrossRef Medline

Siller SS, Broadie K (2012) Matrix metalloproteinases and minocycline: therapeutic avenues for fragile X syndrome. Neural Plast 2012:124548. CrossRef Medline

Silva AJ, Frankland PW, Marowitz Z, Friedman E, Laszlo GS, Cioffi D, Jacks T, Bourtchuladze R, Lazlo G (1997) A mouse model for the learning and memory deficits associated with neurofibromatosis type I. Nat Genet 15 : 281-284. CrossRef Medline

Silverman JL, Smith DG, Rizzo SJ, Karras MN, Turner SM, Tolu SS, Bryce DK, Smith DL, Fonseca K, Ring RH, Crawley JN (2012) Negative allosteric modulation of the mGluR5 receptor reduces repetitive behaviors and rescues social deficits in mouse models of autism. Sci Transl Med 4:131 ra51. CrossRef Medline

Spolidoro M, Baroncelli L, Putignano E, Maya-Vetencourt JF, Viegi A, Maffei L (2011) Food restriction enhances visual cortex plasticity in adulthood. Nat Commun 2:320. CrossRef Medline

Tervonen TA, Louhivuori V, Sun X, Hokkanen ME, Kratochwil CF, Zebryk P, Castrén E, Castrén ML (2009) Aberrant differentiation of glutamatergic cells in neocortex of mouse model for fragile X syndrome. Neurobiol Dis 33:250-259. CrossRef Medline

Tidyman WE, Rauen KA (2009) The RASopathies: developmental syndromes of Ras/MAPK pathway dysregulation. Curr Opin Genet Dev 19: 230-236. CrossRef Medline

Utari A, Chonchaiya W, Rivera SM, Schneider A, Hagerman RJ, Faradz SM, Ethell IM, Nguyen DV (2010) Side effects of minocycline treatment in patients with fragile X syndrome and exploration of outcome measures. Am J Intellect Dev Disabil 115:433-443. CrossRef Medline

van der Vaart T, van Woerden GM, Elgersma Y, de Zeeuw CI, Schonewille M (2011) Motor deficits in neurofibromatosis type 1 mice: the role of the cerebellum. Genes Brain Behav 10:404-409. CrossRef Medline

West AE, Greenberg ME (2011) Neuronal activity-regulated gene transcription in synapse development and cognitive function. Cold Spring Harb Perspect Biol 3:a005744. CrossRef Medline

Wetmore DZ, Garner CC (2010) Emerging pharmacotherapies for neurodevelopmental disorders. J Dev Behav Pediatr 31:564-581. CrossRef Medline

Winarni TI, Schneider A, Borodyanskara M, Hagerman RJ (2012) Early intervention combined with targeted treatment promotes cognitive and behavioral improvements in young children with fragile $\mathrm{X}$ syndrome. Case Rep Genet 2012:1-4. CrossRef

Zoghbi HY, Bear MF (2012) Synaptic dysfunction in neurodevelopmental disorders associated with autism and intellectual disabilities. Cold Spring Harb Perspect Biol 4:a009886. CrossRef Medline 